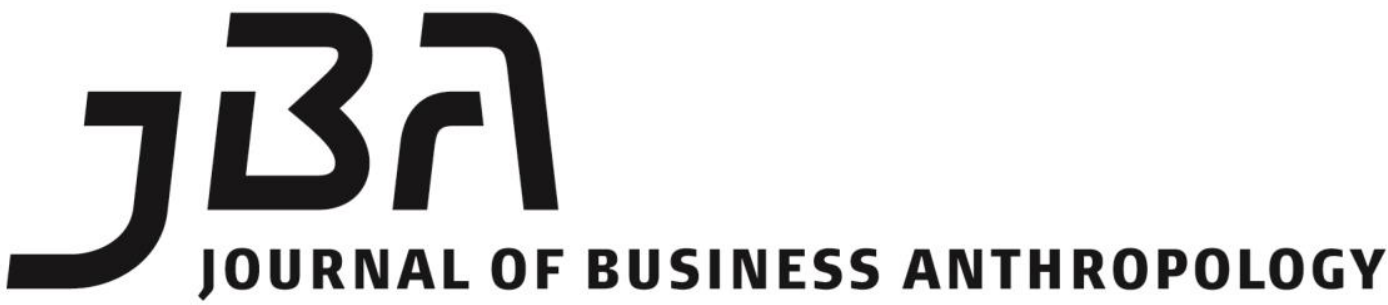

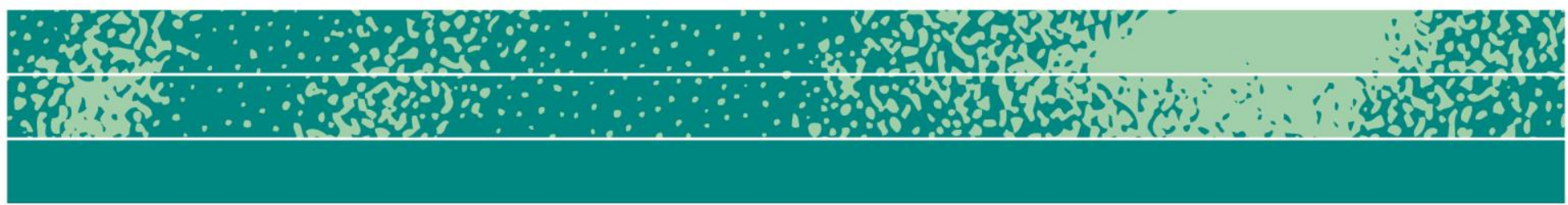

\section{Black Entrepreneurship: Contradictions, Class, and Capitalism $*$}

\author{
Alisha R. Winn
}

\begin{abstract}
This article examines philosophical contradictions faced by black business owners who benefited from racial segregation, yet were often active participants in the civil rights movement. The research provides a critical analysis of the Atlanta Life Insurance Company, examining and revealing conflicting ideas of class and color during Jim Crow, as well as the contradictions of gender, the company's program to "uplift" the community, and hierarchies within the company. This case provides a unique perspective for examining black entrepreneurship, its history, and complexity in the African American community.
\end{abstract}

\section{Keywords}

African Americans, entrepreneurship, community, contradictions, civil rights, segregation, Black elite

\footnotetext{
‡ I would like to thank JBA's anonymous reviews and the editors, Brian Moeran, Elizabeth Briody, and Christina Garsten, for their assistance and support. I would also like to thank Mychele Conway for her insight and taking the time to review this article.
} 
This article examines the late nineteenth and early twentieth century history of the Atlanta Life Insurance Company, a blackowned insurance company that serviced exclusively the needs of African-Americans, first in Atlanta, and later in the southeastern region of the United States. ${ }^{1}$ Its particular concern is with the philosophical contradictions faced by black business owners during the Jim Crow period of racial segregation (1876-1965). ${ }^{2}$

Atlanta is a city known for its established African American community and elite. By 1940, it had by far the most extensive and accomplished black community leadership in Georgia (Tuck 2001: 56); and by 1970, African Americans constituted a majority of Atlanta's population for the first time in history (Rutheiser 1996:62). However, Atlanta's history is also one of tragedy: of racism, as well as civil rights, achievement, success, and change. Simultaneously described as "the cradle of the modern human rights movement," and "one of the poorest and most racially segregated central cities in the United States" (Ruthheiser 1996:3), Atlanta is a city of complexity and imagination.

In the 1880 s, the black population was approximately 9,000 , rising to 35,000 by 1900 . This population growth increased job competition among black and white workers and heightened class distinctions. As a result, the city's white leadership, which feared the social intermingling of the races (Mixon and Kuhn 2005), initiated restrictions to control the daily behavior of the working class.

Racial tensions in the city were further exacerbated by the emergence of a black elite. During Reconstruction, from 1867-76, black men were given the right to vote. They became more involved in the political realm, establishing businesses, creating social networks, and building communities. Many whites were uncomfortable with the advances of this black elite (Mixon and Kuhn 2005), which some believe led to the 1906 Atlanta Race Riots. ${ }^{3}$ After these riots, race-based zoning

\footnotetext{
1 This article expands upon the extensive work of Alexa Benson Henderson (1990), which provides a detailed and thorough history of the development and progress of the Atlanta Life business, and of Carole Merritt (2001), which is an excellent biography of Alonzo Herndon and his family, and includes a short chapter on the establishment of Herndon's insurance company. These two historical studies provide a backdrop for this further analysis of the insurance company.

2 Jim Crow was a 19th century dance ridiculing black people, transformed by the start of the 20th century into a term meaning racial discrimination and segregation (Hine, Hine and Harold, 2004). Jim Crow laws were implemented after the U. S. Civil War to legally enforce segregation, particularly in the South, after the end of slavery (Guest, 2014). These segregation laws throughout the South legally enforced the boundaries between blacks and whites in housing, education, voting rights, property ownership, and access to public services such as transportation, bathrooms, and water foundations (Guest, 2014:216). All African Americans, regardless of their wealth or social standing, had to adhere to these laws (Hine, Hine, and Harold, 2004).

${ }^{3}$ By the end of the riots, although disputed by its low number, 25 Blacks and one
} 
and other more informal means were used to enforce residential and commercial segregation, as well as seating areas for public transportation. ${ }^{4}$ Successful black entrepreneurs concentrated themselves in a segregated business district east of downtown on Auburn Avenue ${ }^{5}$ referred to as "Sweet Auburn," and known as the richest "Negro Street in the World" (Rutheiser 1996:33).

The Atlanta Life Insurance Company (founded 1905) was an institution of triumph, resilience, community uplift, prosperity, and success - characteristics that mirror the life of its founder, Alonzo F. Herndon. ${ }^{6}$ Atlanta Life originated from the Atlanta Benevolent and Protective Association. Founded and led by Peter James Bryant, pastor of the Wheat Street Baptist Church, Atlanta Benevolent provided insurance for small organizations which pooled their money, as each member paid five to 25 cents a week in dues to cover sickness or death (Merritt 2002). The association was one of the numerous small self-help groups that sprang up in African American church communities during the latter half of the nineteenth century (Merritt 2002:76).

In 1904, Georgia passed a law requiring mutual associations to deposit $\$ 5,000$ with the state to protect policyholders. Bryant and his assistant, James Arthur Hopkins, were unable to raise the money, so Herndon paid the deposit and purchased the Atlanta Benevolent and Protective Association from them for $\$ 140$ (Merritt 2002:78). This sale prevented whites from taking over the firm, for both ministers were determined that it remain in African-American hands (Ingham and Feldman 1994:325). After acquiring two other companies, the Royal

white person died. However, there were many blacks and whites injured (Merritt 2002).

${ }^{4}$ Race is a social construction, with great consequences. From at least the seventeenth century on, blackness was conceptualized as the opposite of whiteness and European-ness (Feagan 2001:210) and so functions as the prime racial signifier. "White and "black" are socially constructed categories riveted to a white-dominated structure of oppression, and it is those with the greatest power - white Americans - who have controlled who gets placed where in the continuum's categories (ibid.).

${ }^{5}$ Auburn Avenue was the headquarters for black-own banks, insurance companies and, in 1932, the nation's only black daily newspaper, the Atlanta Daily World (Rutheiser 1996:33). The concentration of black capital in Sweet Auburn helped to define the entrepreneurial Black elite (Rutheiser 1996). It was considered "sweet" because money was sweet, and by 1945 the black-owned businesses of Atlanta had a combined worth nearing \$30 million (Kruse 2005:28).

${ }^{6}$ Herndon was born a slave in Social Circle, Georgia on June 26, 1858, on a slave plantation in Walton County, 40 miles south of Atlanta, run by his white father, slave-owner, Frank Herndon. After emancipation, Alonzo worked as a sharecropper and remained in Social Circle, Georgia until the age of twenty when, with just one year of formal education, he left the small town with $\$ 11$ in his pocket and settled in Jonesboro, Georgia, where he learned the barbering trade (Ingham and Feldman 1994; Merritt 2002). In 1882, he moved to Atlanta, continuing his barbering business, and eventually owning three barbershops (Walker 1998). 
Mutual Insurance Company and the National Laborers' Protective Union, Herndon reorganized all three companies in 1905 to form the Atlanta Mutual (Henderson 1990).

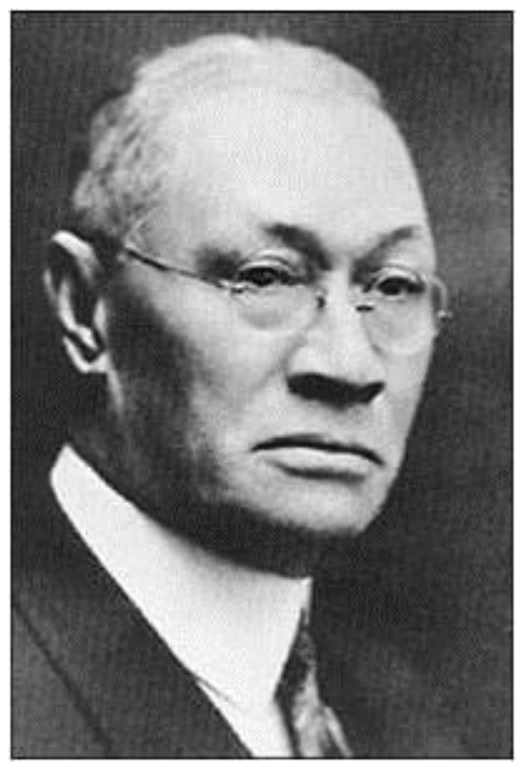

Figure 1: Alonzo F. Herndon, 1858-1927, founder of Atlanta Life in 1905. Herndon owned several properties, including three barbershops, and became Atlanta's first African American millionaire.

By 1915, Atlanta Mutual had become the largest black industrial insurance company in the South and, in 1922, amended its charter, increasing its capital stock to $\$ 100,000$. In this way, it became Georgia's second black legal reserve company, able to sell all classes of insurance, and renamed itself Atlanta Life Insurance Company (Merritt 2002). Atlanta Life stemmed from the "traditions of self-help and mutual aid that sustained African Americans" (Henderson 1990:3). Like other mutual aid society-like businesses operating at this time, the company was characterized by socially-responsible investment. It represented the most effective form of social and economic cooperation among AfricanAmericans, and helped to promote community interests and racial solidarity. Alonzo Herndon's entrepreneurial insurance venture enhanced the course of his life and impacted African Americans in the business world, as well as black communities throughout the Southeastern region of the United States.

The development of black insurance companies and banks began toward the end of the nineteenth and at the beginning of the twentieth century (Lincoln and Mamiya 1990), when African Americans faced severe discrimination in the mainstream insurance industry. Blackowned insurance companies exclusively provided African Americans with a needed service during Jim Crow, and black insurance companies 
emerged as the most successful example of black economic development (Weems 1996). Their financial base came from benevolent and burial associations, as many poor people bought burial plans - paying five to ten cents a week for burial insurance that assured them of a decent burial. The practice of segregated cemeteries in the North and the South, together with the difficulties of obtaining loans from white lending agencies, also led to the establishment of black cemetery associations, out of which many black funeral parlors and mortuaries grew.

In addition to the provision of sick and burial benefits, many insurance companies also became building and loan associations (Lincoln and Mamiya 1990) as they invested in real estate. By providing mortgage loans and venture capital for African Americans during the first half of the $20^{\text {th }}$ century (Weems 1997:210), they helped bridge a critical gap in African Americans' access to housing and home ownership (Butler 1991). In this respect, Atlanta Life helped redefine the characteristics of an insurance company, by not only providing loans for the establishment of African American businesses, churches, and homes, but also by contributing to colleges to support and maintain local historically-black educational institutions, so that it can be said to have been partially responsible for the success of many African Americans and colleges in Atlanta. ${ }^{7}$ Moreover, in the mid-20th century, Atlanta Life assisted black neighborhoods in Atlanta and other southern cities by supporting the Civil Rights Movement, and other areas of community development (Henderson 1990; Merritt 2001).

Renamed the Atlanta Life Financial Group (ALFG) in 2001, the company has consisted of two operating units since August 2012 Atlanta Life Insurance Company and Herndon Capital Management which together provide financial solutions for customers in how to manage their insurance and investments. ${ }^{8}$ In terms of both number of employees and business reach, however, the ALFG has curtailed its operations significantly. ${ }^{9}$ While, in 1980 , there were 520,000

\footnotetext{
7 Alonzo and his son contributed thousands of dollars to support and maintain local historically-black educational institutions such as Spelman, Morehouse, Clark Atlanta, and Morris Brown College.

${ }^{8}$ Atlanta Life Insurance Company is the former name of the entire company, from 1922-2001. For the purposes of this article, I will refer to the company as Atlanta Life in my focus on historical events, practices, and perspectives of the former Atlanta Life Insurance Company. Until fall 2012, Jackson Securities constituted the third company under ALFG. Although due to merge with M.R. Beal \& Co another, minority-owned firm based in New York - the company called off the proposed merger in March 2013. See ALFG website: www.atlantalife.com. ${ }^{9}$ Weems' (1990) analysis of the decrease in assets, and African American firms' staff reduction between the years 1982-1992, relates to Atlanta Life experiences of these reductions from downsizing in the early to mid-1990s. During this time, many pioneers and long-term Atlanta Life employees retired. Due to a decline in business, the first downsizing in the early 1990s meant the closure of many branch offices between 1995 and 1997, and resulted in the sole operation of the home office in Atlanta.
} 
policyholders and $\$ 108.7$ million in assets (Henderson 1990), and (in the early 1990s) close to 300 employees in the home office, and approximately 500 more working in the district offices (which, by 1968, numbered 65, and were to be found as far afield as the Midwestern states of Illinois, Michigan, and Ohio), operations are currently confined to the home office, although the business is licensed in seventeen states.

\section{Telling the Atlanta Life story}

The Atlanta Life Insurance Company's legacy and place in history was unknown to me when, in 2000, I applied to work for the Herndon Home Museum. ${ }^{10}$ I had no inkling of the fascinating story behind this beautiful mansion and its owner. In this respect, my knowledge of the history of African American entrepreneurship was, like that of people in general, severely limited, in spite of numerous writings on the history of black business and insurance (Henderson, 1991; Butler 1991; Gerena 2004; Green and Pryde 1990; Harris, 1936; Walker 1998; Weare 1993). Weems (1997:200) suggests three reasons why black businesses and business people have been under-represented in African American historiography:

There has existed a pervasive belief that black business, historically, represented an unprogressive element of black community life... Second, even when black businesses were considered, their activities were analyzed in a noncomparative vacuum which unduly diminished their significance. Finally, the "racial integration" and "Civil Rights" paradigms of the 1950s and 60s, which focused upon black movement into the American "mainstream," further marginalized community-based black business enterprise.

I soon discovered that the success of the Atlanta-based insurance company dispels the myth of African American business weakness and restores its presence in the African American community. African Americans who lived during the Jim Crow era talk about black businesses and their owners as service providers in their communities, enabling them to thrive despite discrimination and racism. Through ethnographic and archival methods, the research presented here provides a critical analysis of the company, as it examines conflicting ideas of race, class, and gender during the Jim Crow period. ${ }^{11}$

\footnotetext{
${ }^{10}$ The Herndon Home Museum is the former residence of Atlanta Life founder of Alonzo F. Herndon. It was designed by his first wife Adrienne Herndon, without any blueprints, and built by black craftsmen in 1910. In 1973, the Herndon's only child, Norris Herndon, transformed the home into a museum as a memorial to his mother. It is a National Historic Landmark.

${ }^{11}$ During Jim Crow-America, leaders of Atlanta Life faced the challenges of segregation and discrimination in a larger society that affected all African Americans regardless of class. An ethnography of the African American upper class and entrepreneurship is an example of what Laura Nader (1972) has
} 
As I said earlier, my concern is with the philosophical contradictions facing black business owners during Jim Crow: with how they benefited commercially from racial segregation, on the one hand, and yet were often active participants in the Civil Rights Movement, on the other. Their success threatened their ethnic-based monopolies, which were good for black business, as they provided the majority of services in the black community. However, discrimination against black businesses in the larger market place prevented the expansion of their successful business activities beyond the black community.

At the same time, internal divisions in black Atlanta aligned with color and family status - divisions replicated within the company, in terms of corporate hierarchies, gender roles, and the company's "uplift" of the African American community. This itself reflected the Jim Crow dichotomy, as black elite organizations and activities - as well as wellknown wealthy families - operated as a network closed off from the rest of the black community. In addition, although women played vital roles in the company, they faced challenges that limited their mobility and roles in the company. Atlanta Life, like many other black businesses during the Jim Crow period, found itself between two worlds: a segregated America operating within a larger capitalistic society, and a segregated black community.

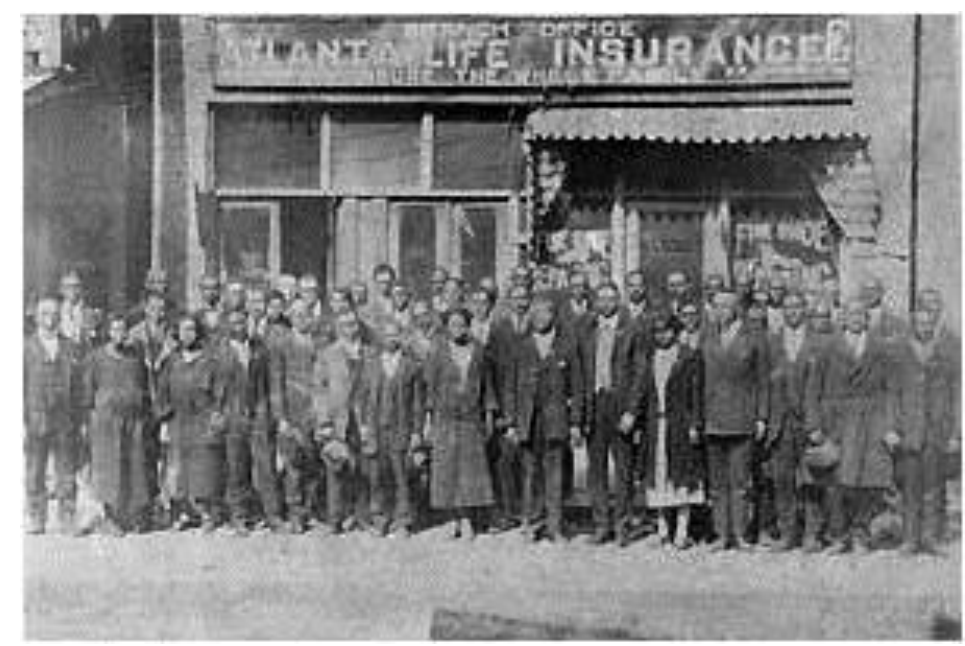

Figure 2: 1922 Atlanta Life Staff, Atlanta, Georgia. Formerly called Atlanta Mutual, the company had several branch offices throughout the southeastern region of the United States during the $20^{\text {th }}$ century. (Courtesy of Herndon Museum)

termed "studying up." Although I am not studying the "colonizers," I am nevertheless analyzing "the culture of power rather than the powerless, the culture of affluence, rather than the culture of poverty" (1972: 289). Therefore, it is important to address the conflicts faced by a company at the forefront of the Civil Rights Movement in Atlanta - a company that clearly benefited from segregation. 
This article takes a critical look at how Atlanta Life built and maintained a successful business in the U.S. South, and at the issues that confronted black business people compared to similar businesses in other ethnic communities. It asks three questions. What were the costs and benefits to business owners, and to members of the community served by them, on the basis of race in the U.S.? What did it mean for business owners to confront race, class and gender issues while accumulating wealth? And how did Atlanta Life business owners and leaders contend with poverty and inequality within the African American community?

\section{Methodology}

As indicated above, my initial involvement with the research presented here developed through my employment at the Herndon Home Museum as an archivist, when I was hired to create the Atlanta Life Photographic Collection. ${ }^{12}$ As part of the National Endowment for the Humanities grant, "Preserving a Business Legacy," I preserved, arranged, and categorized 6,000 Atlanta Life Insurance Company's historic photographic prints and negatives dating from 1918-1993 (the bulk of them from 1950-1970). ${ }^{13}$ I created a finding aid, a detailed record of the content and location of the categorized photographic collection, while other museum staff processed the Atlanta Life documents. All were to be mounted on the World Wide Web to be available to researchers interested in the history of the insurance company.

Through the categorization process, I found thousands of photo prints and negatives of Atlanta Life events and social groups, as I spent a year putting together the collection. It was at my discretion to create titles of series and folders for the photos, and I grouped images based on such classificatory categories as buildings, employees, groups, and events. As I sat processing and preserving, I meticulously took my own notes, and discovered evolving patterns during this process. Clearly, not only did the company provide insurance; it was also involved in a social and economic context beyond anything I had imagined. These images led me eventually to dissertation research on the social and cultural dynamics of the company, and to further exploration of class and the contradictions of entrepreneurship.

For this latter research, I designed a multi-method investigation

\footnotetext{
12 Register of the Atlanta Life Insurance Company Photographic Print Collection 2004 Digital Library of Georgia.

http://dlg.galileo.usg.edu/herndon/atlantalifephotos.html. Processed by Sanford, L. W. Chenault, and author. Websites for the Atlanta Life Negative Collection and Herndon Family Papers are also available: Register of the Atlanta Life Insurance Company Records and Herndon Family Papers. Digital Library of Georgia, Online. Auburn Avenue Research Library, Atlanta-Fulton County Library System. Atlanta, Georgia.

${ }^{13}$ This grant supported the preservation of the history and culture of Atlanta Life through photography and primary documents.
} 
using archival data, participant observation, and in-depth interviews with former and current employees, as well as with non-employees affiliated with the company. ${ }^{14}$ The Herndon Home Museum and the Auburn Avenue Research Library in Atlanta provided the archival data. The Herndon Home Museum's collection of the Atlanta Life photographic collection, transcripts of previous interviews of former employees, the collection series of Atlanta Life employees and events, historical records of the Atlanta Life, and museum newsletters, provided a scope for knowledge about the social and cultural importance of the company that was beyond its business aspects. Using the Auburn Avenue Research Library on African-American Culture and History's collections of Atlanta Life records and its finding aid, I chose and reviewed relevant documents and photographs from the collection, focusing on those related to the Civil Rights Movement, employee information, and Atlanta Life events.

In addition, I focused mainly on interviewees who had experienced life and employment during the Jim Crow Era, and individuals connected to the company during the transition to the desegregation, and postdesegregation periods. I interviewed fifteen Atlanta Life employees (current and former), ten of whom were women, as well as former employees over the age of 60, nearly all of whom had worked for the company for at least 30 years. ${ }^{15}$ Most of the current employees for the Atlanta Life Financial Group, aged 45-65, had worked for the company for 30 years as well. I also interviewed individuals associated with Atlanta Life through the company's financial and professional support of the Civil Rights Movement, because I wanted to understand Atlanta Life's impact and influence on the Civil Rights Movement through the eyes of those who had experienced these events. From these interviews, I attempted to align the study participants' data with archival and visual data to validate the research. For Atlanta Life employees, I analyzed and compared the formal processes of the company's operations, of how it prepared its employees for business, employees' individual journeys through Atlanta Life, their identity within it, and the meanings they attributed to working for such a prestigious and renowned company.

\footnotetext{
14 Occasional participant observation at contemporary Atlanta Life Financial Group events revealed that the company still provided a space for shared identity and economic cooperation, and that it still played a significant role in strengthening the community.

15 Employee interviews took place between 2007 and 2009. Some worked in Atlanta Life branches throughout the country, while others spent their entire Atlanta Life careers at the home office in Atlanta. Many were retired at the time of the interviews. For the purposes of this article, I focus on the experiences of former employees who worked for the company before the 1970s, and Atlanta Life affiliates who witnessed the company's involvement during the Civil Rights Movement. All interviews were audio-taped, transcribed, and edited.
} 


\section{Defining the black elite}

Historically, education, occupation, and income defined the black upper and middle classes. In addition to those in the professions and in government positions, the black upper class included families identified with such service trades as catering, barbering, and tailoring, which brought them into regular contact with upper-class whites (Gatewood 1993: 27). Still, the lines are unclear when constituting classes for African Americans. As Sigelman and Welch (1994:17) put it: "the difficulties of defining class in the black community stem from several social and economic realities of black life: education traditionally has not produced the same income gain for blacks as it has for other racial and ethnic group." So, factors other than purely economic reward are clearly affect the attribution of class - in this instance, varying interpretations of respectability and level of community involvement come into play (Green and Pryde 1990:58).

Gatewood's (2000) description of the black elite identifies its claim to privileged status on the basis of past record of achievements, as well as being antebellum free people of color, culture, education, and, to a lesser degree, wealth. In addition, upper class children in schools reinforced an emphasis on "respectability" and values. Gatewood argued that the educational experience of the black upper class conspired to mold itself into a replica of middle-and upper class white Americans. The "Black Aristocracy," the "respectables of the race," consisted of those who possessed a certain moral character and virtue (2000:113).

Within the African American community, leaders of these institutions, including black entrepreneurs and businessmen, represented upper/middle-class blacks who were highly respected. The description by Kevin Yelvington (1995) of supervisors or managers in a Trinidadian factory parallels this of Atlanta Life power, leadership, and black elite. Power is definitional because it affects who can take up certain positions, and who gets to establish what kind of rules and procedures in a setting such as a factory. Yelvington also sees power as something practiced or exercised, as well as produced, through an economic process. It is achieved by means of resources that are hierarchically distributed $(1995: 12,15)$, so that dimensions of power are relational, structural, definitional, historical, and cultural. Such relational power derives from scarce resources (time, money, commodities), where control over resources by a social entity (an individual, a group, a class) is based on relations between that entity and the resources (1995:17). Atlanta Life's hierarchical structure - revealed in images of its board members, officers, and middle and senior managers, directors, and sales agents attending conferences and events throughout the country, as well as in visits to the company by prominent black international figures - reflects how resources were controlled. 


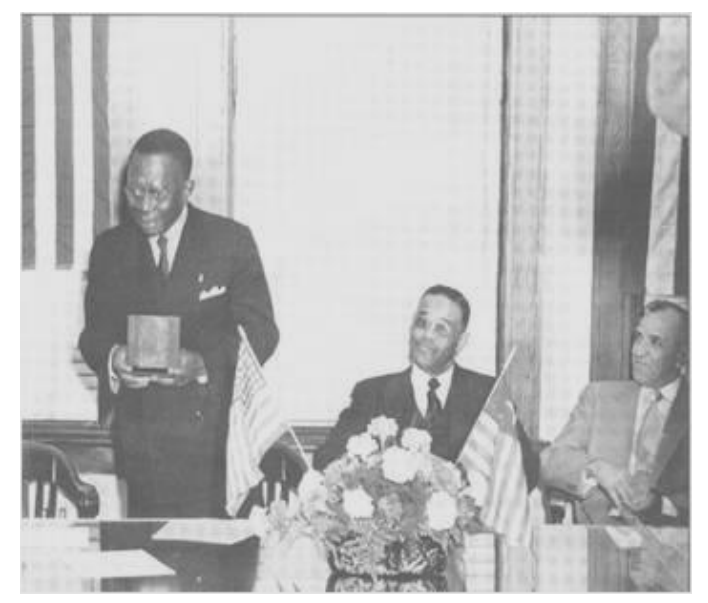

Figure 3: President of Liberia, William Tubman, visits Atlanta Life, 1954. (Courtesy of Atlanta Life Photographic Collection, Herndon Museum)

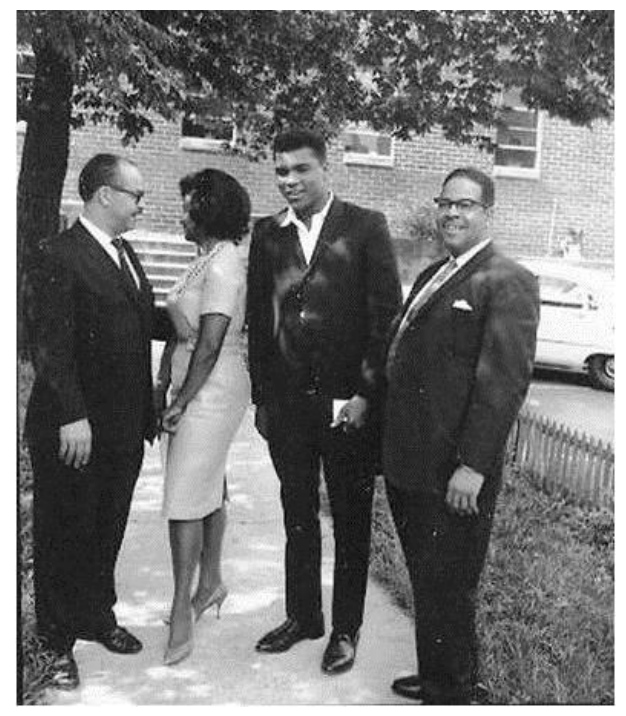

Figure 4: Heavyweight Boxing Champion, Muhammad Ali, visits Atlanta Life, n. d. (Courtesy of Atlanta Life Photographic Collection, Herndon Museum)

Class is used to confound racism, which can also involve, for example, personal conduct and manners (Yelvington 1995). Here we see the involvement of social and cultural capital as issues of class and gender arise. There is a "kind of people," and a "kind of labor" (1995:38), established historically and contemporarily, that correlate with how owners impose their own definitions of social identities on groups (Yelvington 1995:39) - definitions which reinforce conflicts and separations between who are perceived as "acceptable," and those who are not, in society.

For leaders, wealthy owners, and officers of the company, class income differences lay hidden beneath their blackness, concealed by their commonalities: a shared space, identity, and struggle with the lower- 
income members of the African American community. However, many low-income African Americans remained impoverished despite the presence, role, and impact of Atlanta Life within the community. There is a relationship between the formation of collective identities and structural arrangements of power (Gregory 1998), consisting of larger structures of a capitalistic system, which exclude, and alternately include, the African American community and leaders of the institutions: the black elite.

\section{Class: attitudes and prestige}

The majority of employees of Atlanta Life Company were graduates of Atlanta University and many attended First Congregational Church (Tuck 2001:57). The five former women employees I interviewed, who worked for the company from the 1940s to the 1990s, attended historically-black, popular, and prestigious colleges: Spelman, Morris Brown, and Clark College. During one interview, a woman compared and contrasted Atlanta Life's working environment with her current living environment. Her work had indirectly defined her higher-class and educational status, compared to that of other individuals living in her building.

"I say being in a building like this, all these different people from all walks of life... But I don't deal with them because we don't have anything in common, you know. So many different types of people in a place like this. So I say, and I tell people, I say I can't compare that when I was at the Atlanta Life all those women, 150 women or so, because we were more or less kind of on the same level, had something in common."

When I asked what she meant by "same level," she replied: "education and character." She recalled how she and other women workers went to the same type of colleges, adding:

"There at Atlanta Life, people were on the same level... kind of compare this (her residence)...kind of getting to me like the projects what the projects feels like, people from everywhere. Just because I live in the building with them, you know you gonna' speak, but I'm not going to associate with them, cause we don't have anything in common, like we did at the Atlanta Life."

This interviewee equated her current living environment to living in the housing projects. She felt that she did not belong, and appeared to yearn for those times in her past when she was surrounded by Atlanta Life employees. Although women did not earn much income, their employment at Atlanta Life and their education enabled them to move upward in class and separate themselves from lower-income individuals. 
Not all current female employees were educated through the AU Center. ${ }^{16}$ However, they had some form of educational training in business and/or insurance.

Attitudes like this towards non-Atlanta Life employees, as well as towards those with lower-class status, are reflected in the literature on perceptions of the black poor by upper class blacks, with many writers portraying members of the upper class as wanting to separate themselves from the masses (Drake and Cayton 1954).

Class in black America has never been viewed in strictly literal economic terms: the black definition of class embraces style and behavior as well. Hence, it is not uncommon to hear 'that's so ghetto' used to describe behavior associated with poor folk, whether one picks garbage or sets a pick-androll on the basketball court for a living.

(Dyson 2006:xv)

In Black Metropolis, Drake and Cayton (1945:559) present upper-class blacks' description of lower-class blacks in Bronzeville, Chicago, in the 1940s:

Upper-class are very definite in their conception of what constitutes lower-class behavior. It is not poverty that outrages their sensibilities, but lack of decorum - what they call "ignorance," "boisterousness," "uncouthness," "lowbehavior.”

They add (p. 584): "whenever a low-class Negro confronts a Negro of higher status, the atmosphere is sub charged with latent class antagonism." Upper class attitudes toward lower-class behavior reveal that "lower class people are those who give free rein to their emotions, whether worshipping or fighting, who 'don't know how to act,' or dress correctly, or spend money wisely” (ibid. p. 562).

\section{Class: distinction and exclusion}

The black elite leadership, which automatically stratified the black community, in turn perpetuated a space for forms of exclusion. Gatewood's (1990) study of the black aristocracy after Reconstruction reveals how "old families" viewed themselves as the products of a process of natural selection and superior to other blacks in terms of culture, sophistication, and achievement. These beliefs revolved around a "sense of longevity and exclusiveness" (Bowser 2007:143).

\footnotetext{
${ }^{16}$ The black business elite of Atlanta connect to the city's historically-black colleges known today as the Atlanta University (or AU) Center, which consists of Clark Atlanta University, Morris Brown College, Interdenominational Theological Seminary, Spelman College, and Morehouse College.
} 
The lives of the Atlanta Life officers reveal this exclusivity of the black elite. Parties and social interaction with wealthy whites and famous blacks defined an upper class lifestyle led by Norris Herndon and those in his circle, including many of Atlanta Life's management. This prestige also resulted from their helping to "uplift" the African American community, together with the power that was associated with this uplift, while giving to charities, sponsorship, and advertising. Such actions brought more attention and money to the company from black consumers, and contributes to an idea of class as "an identity based on a cultural understanding of one's capital resources and the mode of closure one habitually employs within the objective structure provided by capitalism as totalizing cultural system" (Yelvington 1995: 32). The processes by which Atlanta Life's senior officers sought to maximize rewards by restricting access to resources and opportunities to a limited scale of individuals epitomizes Yelvington's (1995:29) notion of "closure."

For example, the company used to invite district managers in the top selling districts to Atlanta Life's annual Christmas Gala in Atlanta. A former district manager of Miami, Florida recalls how the company rented a Greyhound Bus in Miami in the mid-1960s, before driving through Lakeland, Florida, and picking up managers to take them to Atlanta for the Christmas gala at the Royal Peacock - a local nightclub located on Auburn Avenue, once the hub of African American businesses. The company put the managers up in Paschal's, an African American owned hotel at the time. Not that rewarding employees was anything new. In 1924, the company initiated special incentive campaigns for those who produced the largest debit during a particular time frame (Henderson 1990:93). In 1954, some employee recipients of the Norris B. Herndon Caravan won a free trip to the World Series between the Cleveland Indians and the New York Giants. The image of the winners in front of Progressive Field in Ohio, holding a banner displaying their success, reveals a separating out of certain employees and their families from within the larger African American community. Most female employees, employees in lower level positions, and those who did not produce high enough sales, did not qualify to win all-expenses-paid trips (see Figure 5). Whether intentional or not, this created an exclusion of certain groups - an exclusion that resonated with issues surrounding gender and class, and/or employee level or position, within the context of an African American business. 


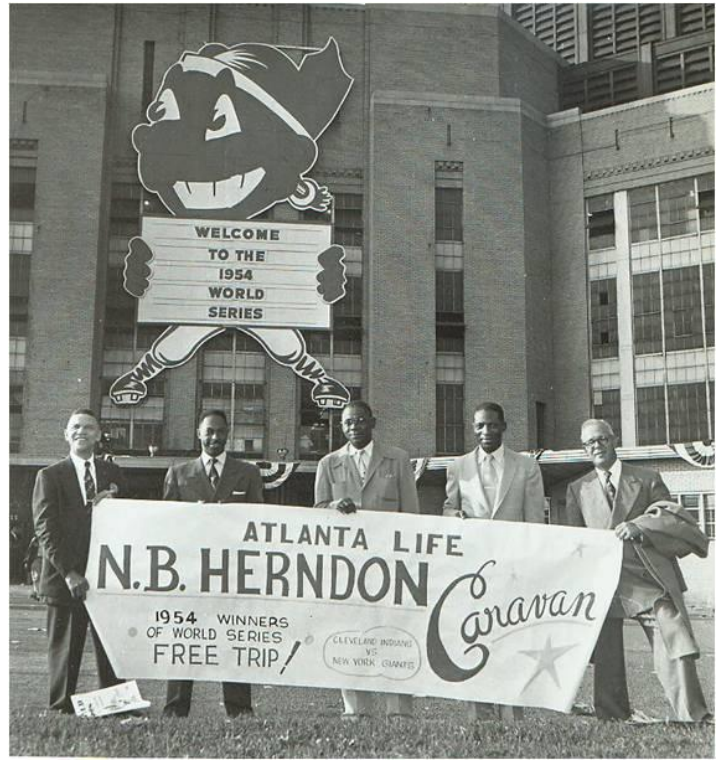

Figure 5: Employees in front of Progressive Field, 1954 (Courtesy of Atlanta Life Photographic Collection, Herndon Museum)

Most female employees did not attend Atlanta Life and National Insurance Association conferences either. ${ }^{17}$ According to one former employee (employed 1959-1991), beneficiaries of the trips included agents, supervisors, area directors, and managers with a high level of sales and productions. Most agents were men who were permitted to bring their wives and families on these trips. This same interviewee added:

"Atlanta Life had these National Insurance Conventions that gave us an opportunity to be exposed to a lot of stuff. My children look[ed] forward to that because we went to various cities. See, those are things that benefit us...I've driven to California...We went to Las Vegas... these are national conventions, you earned these trips."

In short, the company provided a secure space for employees to expand their education and develop their careers, providing opportunities for upward mobility, skill development, status and prestige. The positions offered higher-ranking employees, particularly men, opportunities for travel and leisure that characterized a middle and upper class lifestyle.

\footnotetext{
17 The National Insurance Association, originally known at the National Negro Insurance Association, was founded in 1921 and consisted of the major black insurance companies in the nation. The association had a school called the NIA Institute. Officers served as the principal instructors. Atlanta Life sponsored the trips to the NIA conventions.
} 


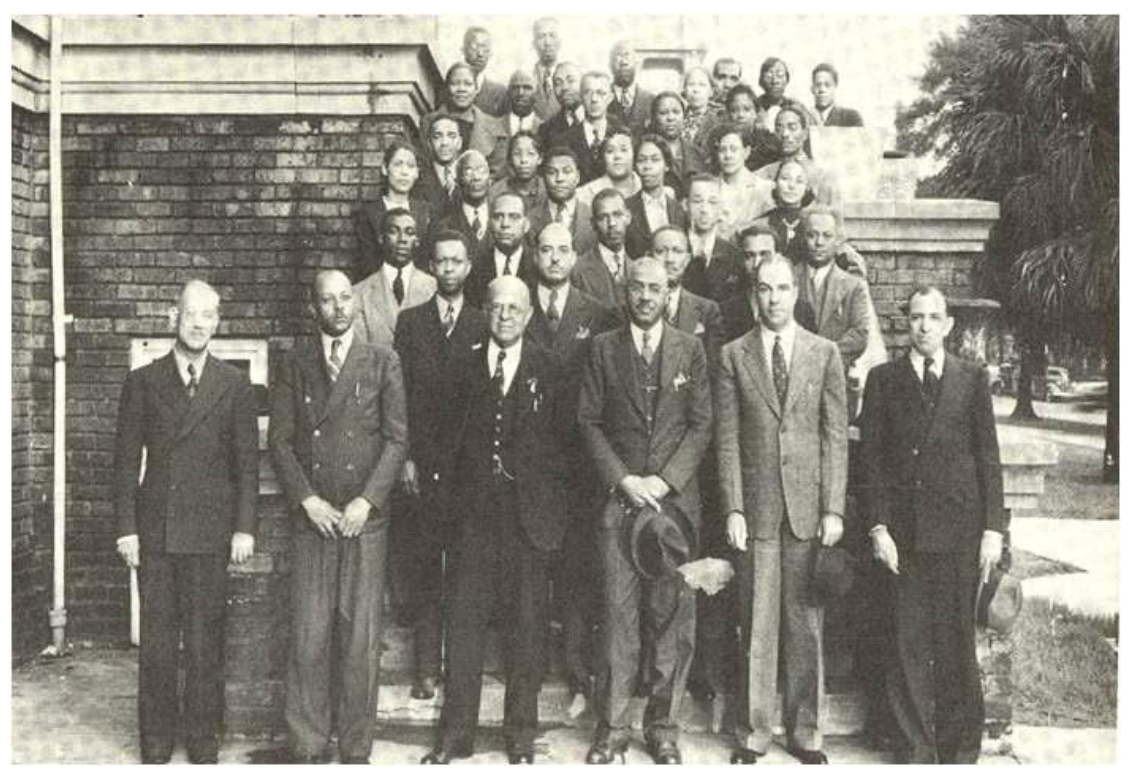

Figure 6: Atlanta Life Auditing School, late 1920s. (Courtesy of Atlanta Life Photographic Collection, Herndon Museum)

\section{Women}

In his description of racial stratification of urban labor markets, Glenn (2002:106), describes the racial and gender differences of black employment between 1865 and 1890:

Black women were even more constrained. Only about 3-4 percent of those in the labor force were employed as skilled craftswomen and professionals. Most of the craftswomen were seamstresses, while the largest group of professional women were teachers. The overwhelming 80-92 percent of black women workers in southern cities were employed as laundresses or in domestic service as maids, cooks, and child nurses.

Therefore, for women, employment with Atlanta Life provided rare opportunities for social and economic mobility during the Jim Crow era. An Atlanta Life affiliate described opportunities for women in the following way:

"You have to remember this was a time when there weren't a whole lot of black folk with good jobs... Most women who were working were either teaching school or they were maids... Women were going to catch that bus in their white uniforms, going to take care of white folks' homes and their kids. And so, to come by a place (Atlanta Life) like this where you have white collar looking people, you know dressed up, come in here working in an office kind of environment... that was impressive and it was an inspirational thing for the broader community." 
Employment by a company like Atlanta Life, then, was prestigious for women. "It was a job that was not a menial job," said one former employee, before continuing:

"You weren't doing any housework, kitchen, cooking... Good jobs, sit down jobs; typewriters and adding machines, bookkeeping. It wasn't the type of jobs that was usually given to young black women at that time. The best job you could get was working at a store somewhere as a sales clerk..."

The majority of the employees who worked for Atlanta Life during World War II were women. As in many other companies, "women were hired in great numbers, taking over the job of making weekly collections from drafted men" (Henderson 1990:142). They proved extremely capable and made a significant contribution to Atlanta Life during the war era (Henderson 1990:143), although most were clerks, not agents, and were only promoted to the role of supervisor, whereas men became officers and managers.

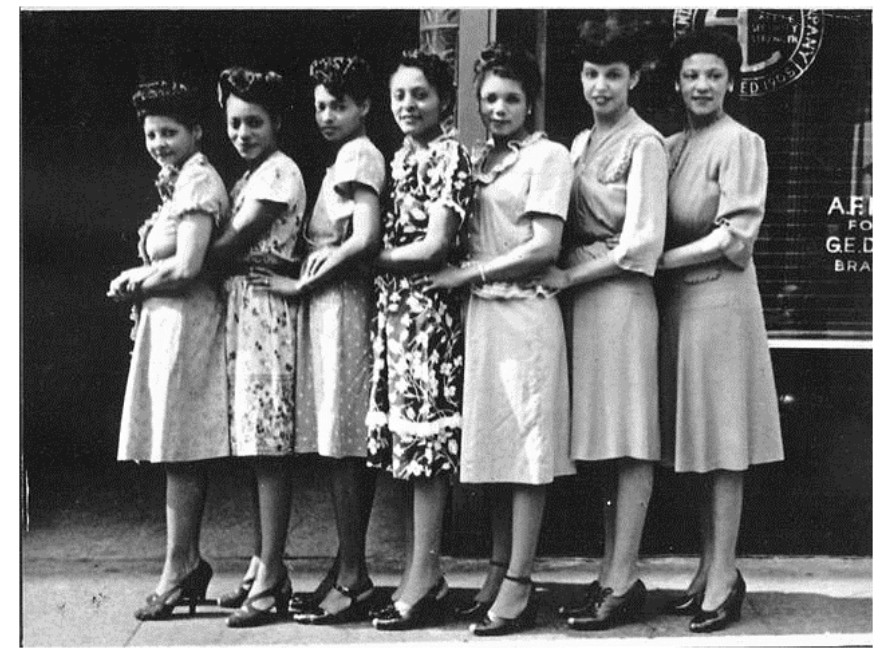

Figure 7: Atlanta Life Female Employees, 1940s. Atlanta Life provided women with better employment opportunities. (Courtesy of Atlanta Life Photographic Collection, Herndon Home Museum)

Female employees played multiple roles pursuing education, supporting agents and supervisors, providing accurate work, and maintaining family roles at home. According to one of the interviewees, half of the women working from 1950 to 1990s were married, so that many of them had to balance work and family responsibilities throughout the decades.

Nevertheless, there were very few rights for women, even in the "white collar" world. Historically women employees did not make a lot of money, nor did they have many rights. According to one retired employee, 
who began working for the company in the 1950s, Atlanta Life leaders asked women applicants if they planned to have children. Having too many children posed a problem, and was grounds for possible termination, although it was never made clear just what number of children constituted "too many." If a woman wanted to come back, she had to write out a statement to that effect: "Once I finish my leave of absence, I would like to come back." As one interviewee acknowledged: "It was a man's world back in the day. Women didn't have too much authority... The men got the jobs first."

One former manager commented that, when he reviewed applications for employment during the 1950s, a woman was required to have her husband's approval to work. Another employee recalled how, as late as 1998, her husband had to agree to the type of retirement settlement that she would get: a lump sum or increments. The employee wanted to get a lump sum, but her husband preferred to get checks. "I thought it was horrible," she said.

At a time when many African Americans, particularly women, could in general only find menial jobs and domestic work, the company offered opportunities, since office or desk jobs were a prestigious form of employment. The company was thus a space, not only for the production of cultural identities, but also of employee power and status, independent of their income level.

\section{Nostalgia and contradictions}

In spite of these clear lines of race, class and gender within Atlanta Life, employees whom I interviewed, and who had worked for the company for at least twenty years, frequently resorted to a nostalgia for the "good old days." In this respect, they occupied a "disclosive space" - meaning "any organized set of practices for dealing with oneself, other people, and things that produces a relatively self-contained web of meanings" (Spinosa, Flores, and Dreyfus 1997:17). Time and time again, I heard comments like, "it was the life," "it was like family," "now things have changed," and "we used to be..." as interviewees expressed a nostalgia and longing for the past that neatly encapsulate present day ideas about segregation - something a sizeable proportion of the African American community now looks upon favorably. As one long-time male employee said of the Board of Directors and senior managers:

"It was like a family affair, you didn't have to worry about, 'Oh Lord here come so and so I can't speak to them'... It wasn't like that. You could speak to any of them... Their problems were your problems..."

One female employee, who began working for the company in 1947, went on maternity leave, pursued another job, and returned to Atlanta Life seven years later. She re-applied and was re-hired, without any problems. 
Her name was still in the records, and she was put back into the same department.

“At that time I didn't think anything about it. That was the first job I ever had. So to come back to it, it just seem like I was coming back home... I enjoyed it thoroughly, working for Atlanta Life; it was like a family...each department depended on the other department for part of their work."

Employees' nostalgia and romanticizing memories of the company present a view of the firm as everyone "getting along" in a "family-like" atmosphere without many problems. They shared much in common, and fully supported one another. Yet my interviews also revealed several contradictions. Some women could obtain better or higher positions in the company from dating officers. They were also discriminated against when it came to pay, and were hired on the basis of skin color, where lighter skinned, or "high yellow," 18 women were likely to be hired, even though they had failed the application test. The same was true of women who had connections to the Atlanta Life leadership. As one interviewee put it: "You could be a dumb black girl and be fair, you could get a job." This is not to infer, however, that skin color was the only criterion used to hire female employees, and unequal practices like this did not deter women from pursuing employment under challenging circumstances. So far as they were concerned, working for the company was better than doing menial work, where they faced both racist and sexist attitudes and practices.

\section{Black business and segregation}

As mentioned earlier, before the Civil Rights Movement and equal opportunity, members of the traditional black elite were confined to segregated environments. "They lived and attended schools in primarily segregated communities. They were generally employed or self-employed in institutions serving the black community" (Benjamin 2005:44). The racism that the traditional black elite experienced was overt, and it was supported and sanctioned by the folkways, mores, and laws of the larger society (ibid.), which limited African Americans' social mobility among whites, while enabling it within the black community. Forced to attend historically-black colleges, African Americans received "an automatic ticket into the black middle class" upon graduation (Bowser 2007:56).

Many black businesses, like Atlanta Life, operated initially in a segregated space. Within this segregated space, service was open to

\footnotetext{
18 "High-yellow" has been used to describe an African American of light or fairskinned complexion. It can also be associated with "mulatto" (having one black parent and one white parent). This term could be interpreted as derogatory based on its usage and circumstance (Gayle 2012).
} 
blacks to provide the services needed in the black community. These included dental and medical services, grocery stores, and schools (Bowser 2007), and there was a small percentage of black professionals serving the black population: primarily small businessmen, ministers, teachers, and undertakers, but also doctors, lawyers, and pharmacists. African Americans found few white-collar opportunities in either the public or private sectors (Harris 1999:1).

Historically, then, segregation shaped African American business. "In the South, ten years after the Civil War, Afro-American businesses did not serve only black clientele. But, the passage of Jim Crow laws in the 1890s changed this pattern and forced all Afro-American businesses into one section of the business world" (Butler 1991:144). Either they had to develop their own institutions, or they had to exist without them (Walker 1991).

This "man-made barrier" (Butler 1991:77), prevented African Americans, by law, from operating their business enterprises in an open market (Butler 1991:77). Slavery, racism, and legal segregation afflicted African Americans in a unique manner unique, which is often characterized as having stunted the development of African American communities and impeded their economic and social integration in larger society (Greenbaum 1991:95).

However, while segregation both stifled and encouraged the development of companies (Greenbaum 1991:104; Jackson 2004, 2006), it also enabled the economic development of black entrepreneurial businesses, which in turn provided services for the African American community. It was not until after Emancipation that modern business enterprise took root among the black elite, thanks to the establishment of the Freedman's Bureau (Frazier 1957). ${ }^{19}$

In this kind of environment, wealthy owners and leaders could themselves relate to the rest of the black community, to some extent at least. They shared a common goal of eliminating discrimination, since wealthy owners did not have full access to the larger capitalist society, nor did they have fully equal rights. Many still had to live in black neighborhoods, and faced discrimination outside the black community. So they were bounded by physical space due to segregation laws, and by economic space globally. Both helped diminish the differences between wealthy owners and the rest of the community (middle, working or lower income), although some employees experienced some aspects of the privileges that came with working for a company like Atlanta Life (that is, there was no competition with whites, an opportunity to grow and

${ }^{19}$ Established March 3, 1865, the Freedman's Savings and Trust Company was a mutual savings bank established for the benefit of black people. It was a nonprofit concern which had no stockholders (Walker 1998). All assets of the Bank were owned by depositors, in proportion to the deposits of each (Osthaus 1976:5). 
develop skills, a safe work environment, and family-like solidarity). In addition, Atlanta Life's attraction and popularity related to the fact that all members of the African American community could acquire simple nickel and dime policies. Atlanta Life provided insurance for everyone, whether poor, working class, or black elite.

\section{Civil rights and black business}

In this shared reality between the black elite and the rest of the African American community, the wealthy owners of Atlanta Life took on the role of fighters for equal rights, and provided assistance in the community. Black businesses in general played a major role in the Civil Rights Movement and in the fight for equality. In addition to providing financial services, for example, African American banks gave members of the African American community a sense of security and confidence in their ability to gain a foothold in mainstream America (Ammons 1996:471). The 1960s were a time when black leadership called for blacks to secure equal access to public accommodation, and to full civil and voting rights. These were crucially important for the development of African American business and investment activities, as well as for overall economic development (Walker 1998:263).

Between 1957 and 1968, black organizations directed the efforts of tens of thousands of people, mostly blacks, in a national civil rights protest movement, the principal features of which are now familiar: raising money, collecting and distributing food, and carefully orchestrating boycotts, sit-ins, and marches (Carson 1993:36). The fight for equality and economic development were the common goals of African Americans and institutions led the community in this movement to change segregation laws. Atlanta Life assisted in voter registration, bailed protesters out of jail, and financed marches/protests. All such activities represented a continuous link with the broad social activism of Alonzo Herndon, and reflected the social consciousness of both the enterprise and his leadership (Henderson 1990).

Atlanta Life's involvement began when Morehouse College students,,, Lonnie King and Charles Black, and other students from the Atlanta University Center, protested against Rich's Department store and ten other businesses that discriminated against blacks. On March 9, 1960, the students drafted a document, An Appeal for Human Rights, which appeared in most of Atlanta newspapers, both white and black, and as a paid advertisement in the Atlanta Journal Constitution. In it, students demanded equal rights and justice in education, housing, employment, voting, hospitals, restaurants, entertainment, and concerts. This was followed a week later by student protests in eleven different places simultaneously throughout the city.

The Atlanta Life Photographic Collection contains hundreds of 
photos and negatives of the civil rights protests in downtown Atlanta. As business people and influential citizens, leaders of Atlanta Life could not watch quietly from the sidelines, as blacks waged a desperate struggle for freedom and equality in America. Instead, these individuals frequently attempted to use their positions in business, and in their communities, to inspire economic, political, and cultural development among AfricanAmericans (Henderson 1990:168).

In the 1950s and 60s, Atlanta Life president Norris Herndon and other Atlanta Life executives had bailed protestors out of jail on many occasions. Now their employees were participating in Civil Rights protests. One former employee, who worked for Atlanta Life from 1947 to the 1990s, described her experience picketing in downtown Atlanta in front of Rich's department store: "I went a whole month there. I was kind of nervous, you know. I said to myself, I hope these white people don't bother me."

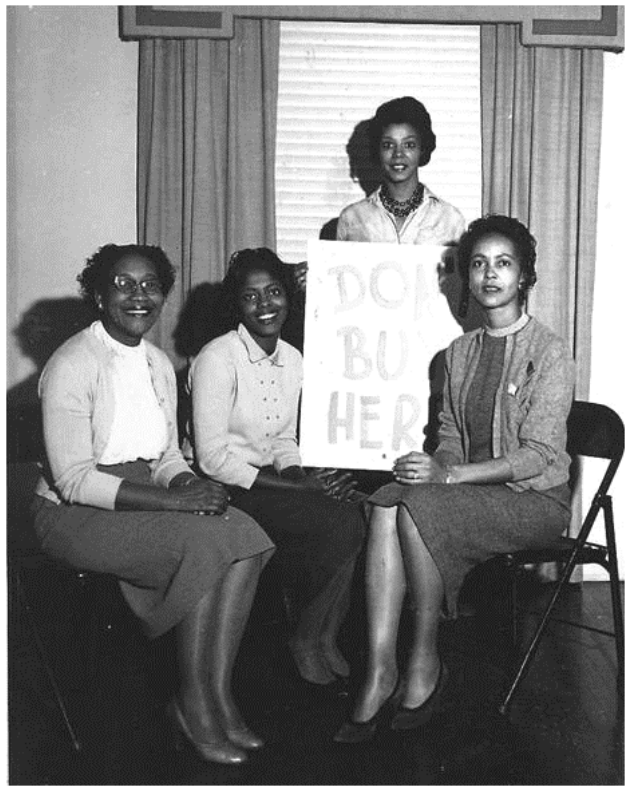

Figure 8: 1960s Civil Rights Protestors. (Courtesy of Atlanta Life Photographic Collection).

Atlanta Life also promoted professionalism in the Civil Rights Movement, giving it a business-like appearance, and even helped create picket signs for protestors. Organizer and leader of the 1960 Atlanta student movement, Lonnie King, recalled how Atlanta Life Vice President, Eugene Martin, spoke with him after seeing one early protest on television. King described Herndon's message as follows:

"Pushing this move, we need to look good, it's Public Relations. The world's going to be looking. They should not see the Atlanta University Center students with rag tag signs... We had the most professional looking signs... Martin 
made it very clear to me when he called me that day about those signs. He was speaking for Mr. Herndon. 'Cause Mr. Herndon had seen our picket signs and he didn't like the way they looked, and felt that if we were going to do this thing and it was right, (whispering), they needed to look good."

On Herndon's order, Martin brought in Atlanta Life artist, Maurice Pennington, to improve the appearance of protestors' picket signs something that reflected past concerns about proper presentation in public, particularly a positive and professional presentation amongst African Americans. Respectability and proper presentation were seen to be extremely important in the rebellion against the "Jim Crow System." After all, respectability is an attribute defined by those in power as part of the ideological "rationale" for their own superior possessions and authority (Greenbaum 2002:22). Charles Black, another leader in the 1960 student movement, had this to say about the picket signs:

"Nice block letters printed on poster board... we probably had the best-looking signs in all the movement, in the whole country... Support we got from Atlanta Life. They had the independence, of course, to be able to do that. Their clientele was black, you know, so it was not possible or easy for them to be reprised against by the established community, 'cause they were a power unto themselves. So they were able to provide that kind of support."

\section{Business for community, business for profit}

It is clear that Atlanta Life used its notoriety, wealth, and status to their social advantage, by participating in the Civil Rights Movement through protests and voter registration. At the same time, however, while supporting the African American community, its management continued to accumulate wealth - something that was common to black businesses in general, particularly during the Civil Rights Movement. The company's involvement, therefore, put it in the forefront of the movement, both socially and economically, as the company used its resources (including advertising, public relations, connections, power, success, and wealth) to confront injustices head on. ${ }^{20}$

Atlanta Life had two missions: one was to "uplift" the African American community; the other, to serve the public as a business. Like any other company, Atlanta Life functioned according to the rules of capitalism and was part of the American economic system. As Herndon himself is reputed to have said in an interview: "America is a capitalistic country, and I am a capitalist" (Kimbro and Hill 1992:61). This comes across in two of his business activities. First, Herndon father and son

${ }^{20}$ It is also possible that this publicity encouraged or influenced members of the African American community to take out insurance policies from Atlanta Life. 
owned and ran prestigious barbershops whose all black barbers served "whites only" in Atlanta (until protests following the Civil Rights Bill enforced a change). ${ }^{21}$ This was in accordance with Jim Crow laws, and shows how Alonzo Herndon used the segregated market to his advantage: "he would engage two worlds of business, two separate markets, turning the deep and constant racial divide to his own advantage" (Merritt 2002:69). As one former Atlanta Life employee put it:

"Mr. Herndon made his money in segregation; opened a barbershop on Peachtree Street. That's where he made his money; the money that enabled him to open up the Atlanta Life Insurance Company to start it...cause when they started, think how the black companies grew so Mr. Herndon started Atlanta Life from barbershop money from white people; he made a whole lot of money."

The question is: was he motivated by money? Or was he trying to help black barbers protect their image and preserve their tradition of "best service," and in so doing support the black community? After all, he - and his son Norris - were stuck in a quandary. Thanks to segregation, "white" money had enabled the Herndons to set up and run an insurance company in the first place, and attract black customers. This was the reality that faced the leaders of many African American businesses during Jim Crow.

Second, Atlanta Life provided the wherewithal, promoted, and exhibited a motion picture, The Parade of Negro Progress, which highlighted and celebrated different aspects of "Negro life." In spite of this cultural façade, however, it appears that for senior management "the primary object of the film was to make money, but in a clean and honest way... to build friendships, and to show others" what the company was doing (Tidwell and Sanders 2007:171).

This idea of making corporate profit behind the veil of community "uplift" mirrors Weems' (2002:405) "black businessman as villain" thesis, which, building on earlier critique (Harris 1936), argued that blackowned businesses exploited lower income black consumers (Weems 2002:406). Like other black middle class business owners, Herndon and his senior management promoted racial pride and unity as a cover-up to gain black support for middle class controlled businesses (Harris 1936:50). This raises a series of questions. Were Atlanta Life leaders' seemingly altruistic actions a genuine strategy to strengthen the black community? Or were they designed to increase wealth and power for

21 In November 1965, members of the Southern Christian Leadership Conference (SCLC) protested at the Herndon Barber Shop for only serving whites, refusing to serve black customers. The Civil Rights Act of 1964 excluded barbershops not located in hotels or other places of public accommodation. A few days after the incident, blacks were able obtain haircuts at the barbershop, with the stipulation that not too many blacks come at one time (Britton, 1965). 
themselves? Did these acts of kindness towards the community serve as a cushion, or back-up, if management was accused of conducting business "only for profit"? Did Atlanta Life's leaders perpetuate the "Black Villain Theory" (Weems 2002)?

As we have seen, the company's function within the capitalistic system was twofold: the company took care of the community, and the community took care of the company. This reciprocal system of cooperation worked successfully. In Atlanta capitalist society, black businesses made money, even though they operated in an environment of racism and predation, created and sustained by the larger capital market and legally enforced rules. At the same time, the fact that Atlanta Life employees protested against discriminatory businesses dispels this Black villain theory. Although they did not have to worry about losing their jobs, and knew that the company would bail them out of jail if necessary, their protests were made not without risk. They could be arrested, spend time away from their families, or be beaten or killed. While having the protection of their employers, therefore, employees sacrificed themselves to some degree.

It is difficult now to determine how much tension Atlanta Life's leaders and officers had to contend with at the time. Indeed, so far as they were concerned then, economic growth and uplift of the African American community may not have been a contradiction at all. They may not have needed to engage in "uplift" as a means to establish wealth and power, because African American businesses owed their origins to a more communal form of organization, and only later developed more obviously "capitalist" characteristics. In Greenbaum's words (1991:104): "black mutual benefit societies by the turn of the century were becoming increasingly entrepreneurial, with a declining emphasis on fraternalism and ritual." In other words, Atlanta Life's insurance business, which originated as a mutual aid society, "played a vital role in capitalizing the development of businesses and homeownership in black communities," so that its own expansion and economic growth could have contributed to the direction then taken by the company, as traditional overlaps between "family, residential, and occupational ties" were changed. In this, it adhered to developments in business more generally, where "increasing size inevitably attenuated intimacy and growth in scale conditioned hierarchical structures" (Greenbaum 1991:99).

\section{Conclusion}

African Americans faced a unique dilemma: how could, and should, black business contend with Jim Crow laws? Economic segregation - described by John Sibley Butler as an "economic detour" (1991:144; Stuart 1970) makes the African American experience unique, in that it posted many negative aspects. First, it prevented blacks, particularly businessmen and women, from competing in a larger market (Oliver and Shapiro 
2007:103), and restricted them to their own group or servicing whites only, thereby limiting economic success on a larger scale. Second, it limited black consumer choices when purchasing goods and acquiring insurance in the larger market. In spite of these constraints, African Americans developed businesses by numerous means. Atlanta Life thrived on the crest of segregation (Merritt 2002:84), strengthening the relationships between the company and the community, and while pursuing economic development.

Segregation also enabled black entrepreneurs to accumulate more wealth from the black community, resulting in greater class differences, which created larger divisions in the black community as blacks carved out social spaces within which their alternative visions of society and community could thrive (Glenn 2002: 127). In these spaces, blacks built an oppositional culture, one that emphasized collectivist values, mutuality, and fellowship (Glenn 2002:127). It placed company leaders in a position to uplift the community, while black business owners could simultaneously increase their wealth.

Most former and current employees viewed the company as a family. These unique aspects of African American business in a shared experience of a "family" represented a fascinating combination of security, support, protection, solidarity, class, gender, exclusion, and inclusion - all affected by segregation and desegregation. The recurring theme, "like a family," illustrates both the functions and dysfunctions of any family, together with its contradictions. From interviews, archival data, and literature, I have shown how such contradictions counteracted the romanticism of a "family-like" organizational culture: stories about low pay, poor leadership, betrayal, disconnections between community and customers, discriminatory hiring practices, and discrimination of female employees. Despite these issues, the company continued on its successful path.

Atlanta Life was a symbol that affirmed black success, providing a space for upward social and financial mobility for its employees. A segregated space provided opportunities: the right to succeed economically, to obtain an education and a decent job, and to participate in social activities. But segregation also had consequences outside the African American community: blacks experienced discrimination, racism, violence, inequality, and humiliation. The African American community provided a market for black businesses during Jim Crow - businesses that became a paradox of community solidarity, as they created an opportunity for African Americans to act and demand equal rights.

Many former employees referred to the company as "the Atlanta Life," as if the firm were an "economic entity" (Ingham and Feldman 1994:325) - monumental, with a sense of honor and sacredness. Former Atlanta Life employees romanticized the company and showed their loyalty to it as they described its business. Employment in the company 
appears to have outweighed the many challenges, issues, and contradictions faced by employees, officers, and leaders. A common refrain in the interviews I conducted was: "Atlanta Life was such a great place to work for, and to be a part of." Most employees, former or current, had a sense of pride to work for the company. Entrepreneurship changed the meaning of work for African Americans in that it gave them autonomy for their own way of life, setting their own standards of business, wealth, and success.

This research has revealed the longstanding patterns of corporate social responsibility in African American firms, and how the shared struggle for equal rights and fair treatment transformed business enterprises. It has examined past and present relationships between the community and Atlanta Life, and the peculiar role that segregation played in reinforcing the solidarity between the insurance company and the wider African American community. As one of the largest and most successful African-American financial institutions in the country during the 20th century, Atlanta Life's resilience throughout the years confirms its legacy, perseverance, and determination. At the same time, this research has brought to light some of the complexities and paradoxes found in the African American community, as Atlanta Life played multiple roles to assist and impact it. In these respects, this research challenges how we should henceforth view black business and its multiple roles, on the one hand, and African American communities, on the other.

\section{References}

Ammons, L. 1996. 'The evolution of Black-owned banks in the United States between 1880s and 1990s.' Journal of Black Studies 26(4):467-48.

Bowser, B.P.2007. The Black Middle Class: Social Mobility and Vulnerability. Boulder, Co: Lynne Rienner Publishers.

Britton, J. H. 1965. 'G.A. Negro shop finally agrees to clip Negroes hair.' Jet Magazine. December 16.

Butler, J. S. 1991. Entrepreneurship and Self-Help among Black Americans. Albany, NY: SUNY Press.

Carson, E. D. 1993. A Hand Up: Black Philanthropy and Self-Help in America. Washington, D.C.: Joint Center for Political and Economic Studies Press.

Drake, St. C. and H. R. Cayton. 1945. Black Metropolis: A Study of Negro Life in a Northern City. Chicago: The University of Chicago Press.

Dyson, M. E. 2005. Is Bill Cosby Right? Or Has the Black Middle Class Lost its Mind? New York: Basic Civitas Books.

Frazier, F. E.1957. Black Bourgeoisie. New York: Free Press. 
Gatewood, W. B. 1993. Aristocrats of Color: The Black Elite, 1880-1920 Bloomington: Indiana University Press.

Gatewood, W. B. 2000. 'Aristocrats of color: The educated Black elite of the post-reconstruction era.' The Journal of Blacks in Higher Education 29:112-118.

Gayle, A. 'Light supremacy: colorism and the black man.' The Hilltop: The Student Voice of Howard University. February 26, 2012.

http://www.thehilltoponline.com/life-style/light-supremacy-colorismand-the-black-man-1.2706908\#.UzSzwV409Zc. (Accessed March 27, 2014).

Glenn, E. N. 2002. Unequal Freedom: How Race and Gender Shaped American Citizenship and Labor. Cambridge, Massachusetts: Harvard University Press.

Green, S. and P. Pryde.1990. Black Entrepreneurship in America. New Brunswick, NJ: Transaction Publishers.

Greenbaum, S. 1991. 'A comparison of African American and EuroAmerican mutual aid societies in 19th century America.' The Journal of Ethnic Studies 19(3): 95-119.

Greenbaum, S. 2002. More than Black: Afro-Cubans in Tampa. Gainesville, FL: University of Florida Press.

Gregory, S. 1998. Black Corona: Race and the Politics of Place in an Urban Community. Princeton, New Jersey: Princeton University Press.

Gerena, C. 2004. 'Urban entrepreneurs: the origins of Black business districts in Durham, Richmond, and Washington, D.C.' Econ Focus. Federal Reserve Bank of Richmond. Virginia. pp. 36-39.

Guest, K. J. 2014. Cultural Anthropology: A Toolkit for a Global Age. New York: W.W. Norton \& Company.

Harris, A. L. 1936. The Negro as Capitalist: A Study of Banking and Business among American Negroes. New York: Negro University Press.

Henderson, A. 1990.The Atlanta Life Insurance Company: Guardian of Black Economic Dignity. Alabama: University of Alabama Press.

Hine, D.C., Hine, W. C. and S. Harold. 2004. African Americans: A Concise History. New Jersey: Pearson Education.

Ingham, J.N. and L.B. Feldman. 1994. African-American Business Leaders: A Biographical Dictionary. Westport, Connecticut: Greenwood Press.

Jackson, A.2004. African Communities in Southeast Coastal Plantation Spaces in America. PhD Dissertation. University of Florida. Department of Anthropology. Gainesville, Florida.

Jackson, A. and A. Burns. 2006. 'Ethnohistorical study of the Kingsley plantation community.' Atlanta: National Park Service, Southeast Regional Office, Cultural Resources Division. 
Kimbro, D. and N. Hill. 1992. Think and Grow Rich: A Black Choice. New York: Fawcett Books.

Kruse K. M. 2005. White Flight: Atlanta and the Making of Modern Conservatism. Princeton and Oxford: Princeton University Press.

Lincoln, E. C. and L. H. Mamiya.1990. The Black Church in the African American Experience. Durham and London: Duke University Press.

Merritt, C. 2002. The Herndons: An Atlanta Family. Athens and London: University of Georgia Press.

Mixon, G. and C. Kuhn. 'Atlanta race riot of 1906.'.The New Georgia Encyclopedia Georgia Humanities Council and the University of Georgia Press. September 23, 2005.The University System of Georgia/GALILEO, and the Office of the Governor.

www.georgiaencyclopedia.org/nge/Article.jsp?id=h-3033. (Accessed January 2009).

Nader, L. 1972. 'Up the anthropologist: perspectives gained from studying up.' In Dell Hymes (ed.) Reinventing Anthropology.pp.284-311. N.Y.: Pantheon Books.

Oliver, M. L. and T.M. Shapiro. 2007. 'Wealth and racial equality.' In Michael T. Martin and Marilyn Yaquinto (eds.) Redress for Historical Injustices in the United States: On Reparations for Slavery, Jim Crow, and Their Legacies. Durham and London: Duke University Press.

Osthaus, C. R. 1976. Freedmen, Philanthropy, and Fraud: A History of the Freedman's Savings Bank. Chicago: University of Illinois Press.

Rutheiser, C. 1996. Imagineering Atlanta: The Politics of Place in the City of Dreams. London: Verso.

Sigelman, L. and S. Welch. 1994. Black Americans' Views of Racial Equality: The Dream Deferred. Cambridge University Press: New York, NY.

Spinosa, C., F. Flores, and H. Dreyfus. 1997. Disclosing New Worlds: Entrepreneurship, Democratic Action, and the Cultivation of Solidarity. Cambridge and London: MIT Press.

Stuart, M. S. 1970. An Economic Detour: A History of Insurance in the Lives of American Negroes. New York: Wendell Malliet and Company.

Tidwell, J. E. and M. A. Sanders (eds.). 2007. Sterling A. Brown's: A Negro Looks at the South. New York: Oxford University Press.

Tuck, S.G. N. 2001. Beyond Atlanta: The Struggle for Racial Equality in Georgia, 1940-1980. Athens, Georgia: University Georgia Press.

Walker, J.E.K. 1998. The History of Black Business in America: Race Capitalism, Race, Entrepreneurship. New York: Macmillan Library Reference.

Weare, W. 1993. Black Business in the New South: A Social History of the North Carolina Mutual Life Insurance Company. Durham: Duke University 
Press.

Weems, R.E. 1996. Black Business in the Black Metropolis: The Chicago Metropolitan Assurance Company, 1925-1985. Bloomington: Indiana University Press.

Weems, R.E. 1997. 'Out of the shadows: business enterprise and African American historiography.' Business and Economic History (26)1: 200-212.

Weems, R.E. 2002. 'Where did all our consumers go? Historic Blackowned businesses and the African American consumer market.' In Jalloh, Alusine and Toyin Falola, (eds.) Black Business and Economic Power. pp. 405-423. New York: University of Rochester Press.

Yelvington, K. 1995. Producing Power: Ethnicity, Gender, and Class in a Caribbean Workplace. Philadelphia: Temple University Press.

Alisha R. Winn is an applied cultural anthropologist whose research has focused on heritage preservation in African American communities, museums, educational disparities, employment, and identity. Her present research focuses on the preservation of the local history of a historic African American community in West Palm Beach, Florida, and an exploration of college students' cultural and religious beliefs, affecting classroom participation and academic success. She is currently Assistant Professor in Anthropology in the Department of Sociology at Fayetteville State University. She may be reached at awinn1@uncfsu.edu 